\title{
Comparison study between the efficacy of immune complex and conventionally live vaccine against Gumboro disease in broilers
}

\author{
F.A. Isihak ${ }^{1}$, H.Kh. Ismail' ${ }^{\mathbb{D}}$ and A.A. Wahid ${ }^{3} \mathbb{D}$ \\ ${ }^{1}$ Department of Microbiology, ${ }^{2}$ Department of Pathology and Poultry Diseases, College of Veterinary Medicine, University \\ of Mosul, Mosul, ${ }^{3}$ General Manager, Yarabarz Company for Poultry Feeding and Veterinary Services, Erbil, Iraq
}

Article information

Article history:

Received June 16, 2020

Accepted August 3, 2020

Available online October 1, 2021

\begin{tabular}{l}
\hline Keywords: \\
Broiler \\
IBD \\
Icx \\
Immunity \\
ELISA \\
\hline
\end{tabular}

Correspondence:

F.A. Isihak

fanar1976@uomosul.edu.iq

\begin{abstract}
This study aimed to evaluate the immune response and histological changes of two Gumboro disease vaccines. Two hundred, days old broilers were divided into 4 groups: group A was vaccinated with live attenuated infectious bursal disease (IBD) vaccine at 7 and 21 days of age, group B was vaccinated with Immune-Complex vaccine (Icx) at first day old, then all broilers of the groups A, B and C were vaccinated with ND vaccine at 10 and 24 days, while the group D was negative control. The blood was collected at 1, 7, 14, 21, 28 and 35 days of age to obtain serum for ELISA. Samples of bursa from broilers of all groups at 14 and 28 days of age were submitted for histological examination. As a result of vaccination in group A the antibody titers are elevated after the 1st and 2nd dose of vaccination at 7 and 21 days. In group B this titer is increased from 21 day of age and reaches to peak at 35 day $7810 \pm 858$ with significant difference, while in unvaccinated groups $\mathrm{C}$ and $\mathrm{D}$ the titer decreased gradually. The histological examination of bursal sections in group A and B varied at 14 and 28 days post vaccination and showed degeneration and necrosis of follicular lymphocytes compared with group and $\mathrm{D}$. Thus we conclude that (Icx) vaccine improves the immune response after IBD and ND vaccination in comparison with live IBD vaccine.
\end{abstract}

DOI: 10.33899/ijvs.2020.127366.1499, (CAuthors, 2021, College of Veterinary Medicine, University of Mosul.

This is an open access article under the CC BY 4.0 license (http://creativecommons.org/licenses/by/4.0/).

\section{Introduction}

Infectious bursal disease (IBD), also called Gumboro disease is a severe and contagious viral disease of young chicks associated with high morbidity and mortality. It is a major poultry infection worldwide (1). The virus is a cause by birnavirus, double stranded RNA virus, bi-segmented, highly resistant to the environmental circumstances (2). Vaccination is the standard approach that used to control IBD in chickens (3). Parent stock immunization is practical to provoke humeral immune response that will be transmitted to the offspring (passive immune response) that will guard the young chicks for the early stage of life (4). An international trend of poultry industry is to shift to words to hatchery vaccination. Immune complex IBD vaccine is attending the needs for hatchery vaccination (5). Numerous vaccines are available commercially for the control of IBD infection in poultry. Immunization against IBD via drinking water has been practiced in the farm with live attenuated vaccines of much residual pathogenicity. However, the live vaccines, particularly more hostile strains, produce troubles, such as bursal tissue destruction, immunosuppressive effect, weakly protected chickens, and the hazard of mutating to virulence. Furthermore, some of classical vaccines have been described with low efficiency, because of the occurrence of highly virulent variant strains of IBD in latest decade (6). Hatchery vaccination is growing to become appropriate trend because of the accumulative capability of poultry producing concerns, and the commitment to better master of the vaccination processes using automated tools, either via subcutaneous injection at day-old, or in ovo vaccination (7). Novelties in equipment's have allowed the expansion of innovate vaccines generations that are capable to evade the 
neutralizing influence of maternally derived antibodies (MDAbs) and consequently are suitable for used as a hatchery vaccine (8). This study is an effort to evaluate the immune response and the histological changes in broilers using two different genera of vaccines against IBD on the bursal tissue response.

\section{Materials and methods}

\section{Broiler chicks}

Two hundred, one-day old broiler chicks (Ross 308) were divided randomly in to 4 groups each group 50 chicks. Group A was vaccinated with live attenuated IBD vaccine (Bursine ${ }^{\circledR}$ ) (Lukert-intermediate strain) (Zoetis-USA) at 7 and 21 days of age via drinking water, group B was vaccinated with Immune-Complex vaccine (Icx) which contains live intermediate plus strain with specific antibodies (Anigen-Antibody complex vaccine) (ZoetisUSA) by subcutaneous injection of $0.2 \mathrm{ml}$ of vaccine/chick in back of neck at 1 day old chicks (DOC), then all chicks of the group A, B and C were vaccinated with Newcastle Disease vaccine (La Sota strain) (Zoetis-USA) at 10 and 24 days of age via drinking water, while the group $\mathrm{D}$ considered as negative control (no vaccination).

\section{Blood samples}

The blood samples $1-2 \mathrm{ml}$ were collected randomly by slaughtering or from the wing vein of chicks at 1, 7, 14, 21, 28 and 35 days of age to obtain serum. The serum from each sample was separated by centrifugation $1500 \mathrm{rpm} / 15$ min and stored in properly labeled vials at $-20^{\circ} \mathrm{C}$ for further processing. The serum from blood samples of DOC were assessed firstly for detection of maternally derived IBD antibodies (MDAbs) then to determine the optimal timing of live IBD vaccination in these chicks (9).

\section{Enzyme Linked Immuno-Sorbent Assay (ELISA)}

Sera were tested to determine the antibody titers against IBD and ND in these groups to evaluate the humeral immune response against IBD which produced by the 2 different IBD vaccines. The procedure for ELISA Kits of IBD and ND were performed according to the manufacturer instructions (SYNBIOTICS/ ProFLOK /Zoetis/USA).

\section{Chick's body weight}

The body weight of chicks was calculated weekly to determine any differences of this parameter between groups.

\section{Pathology}

Selected samples of bursa from the chicks of all groups at 14 and 28 days of age were submitted for histological examination. Tissue section of these organs were removed and fixed in $10 \%$ of neutral buffered formalin. All tissue samples were embedded in paraffin wax, sectioned at $5 \mu \mathrm{m}$, then passing on clean glass slides and stained routinely with Hematoxylin and Eosin (H\&E) stains for detection of histological changes by light microscope $(10,11)$.

\section{Statistical analysis}

Statistical analysis was carried out using SPSS version 19, the titers and body weights were analyzed and compared using Duncan's test (12).

\section{Results}

Despite of multiple vaccinations of IBD, the antibody titer against IBD is still different depending on several factors which affect the vaccination process. Currently, vaccines against IBD are selected exclusively on the ability to produce specific Abs. The MDAbs titer in DOC was homogenous between groups, then this titer decreased at 7 days of age in all groups of this study. As a result of vaccination in group A the Abs titer was elevated after the $1^{\text {st }}$ and $2^{\text {nd }}$ booster dose of vaccination at 7 and 21 days of age. In group B this titer was increased from 21 days of age and reached to peak at 35 days $7810 \pm 858$ with significant difference in comparison with other groups particularly group $\mathrm{A}$. While in both non vaccinated groups $\mathrm{C}$ and $\mathrm{D}$ the titer decreased gradually till the end of study (Table 1).

Table 1: Symbiotic ELISA Mean of antibodies titer against IBD \pm SE, with two different IBD vaccines

\begin{tabular}{lcccccc}
\hline \multirow{2}{*}{ Groups } & \multicolumn{5}{c}{ Mean of antibodies titer against IBD (age /days) } \\
\cline { 2 - 6 } & 1 & 7 & 14 & 21 & 28 & 35 \\
\hline Group A & $5881 \pm 774 \mathrm{a}$ & $2917.7 \pm 364 \mathrm{a}$ & $3864 \pm 297 \mathrm{a}$ & $2991 \pm 650 \mathrm{ab}$ & $3827 \pm 456 \mathrm{~b}$ & $4670 \pm 412 \mathrm{~b}$ \\
Group B & $5963 \pm 480 \mathrm{a}$ & $2895 \pm 427 \mathrm{a}$ & $3482 \pm 258 \mathrm{a}$ & $4653 \pm 642 \mathrm{a}$ & $7200 \pm 747 \mathrm{a}$ & $7810 \pm 858 \mathrm{a}$ \\
Group C & $6011 \pm 140 \mathrm{a}$ & $2951 \pm 294 \mathrm{a}$ & $1994 \pm 431 \mathrm{ab}$ & $1244 \pm 294 \mathrm{bc}$ & $378 \pm 226 \mathrm{c}$ & $358 \pm 206 \mathrm{c}$ \\
Group D & $5898 \pm 323 \mathrm{a}$ & $2936 \pm 347 \mathrm{a}$ & $1459 \pm 348 \mathrm{~b}$ & $845 \pm 169 \mathrm{c}$ & $272 \pm 163 \mathrm{c}$ & $296 \pm 172 \mathrm{c}$ \\
\hline
\end{tabular}

$\mathrm{a}, \mathrm{b}, \mathrm{c}$ The different superscript in each column means statistically different significantly at $\mathrm{P}<0.05$.

In table 2 the Abs titers against NDV in group A showed significant increase at 14 and 21 days of age $4269 \pm 543,2631 \pm 459$ in comparison with other groups, no significant difference between groups at 28 days of age except group $\mathrm{D}$, while at 35 days a significant increase in
Abs titers $5940 \pm 1685$ showed in group $\mathrm{C}$ when compared with other vaccinated groups A and B with Newcastle disease vaccine.

The significant differences in body weight was appeared at 14 days of age in group $\mathrm{C}$ and $\mathrm{D}$. The results at 28 days 
of age showed significant increase of body weight in group $\mathrm{B}, \mathrm{C}$ and $\mathrm{D}$ compared with $\mathrm{A}$, while the final results at 35 days of age showed significant increase in body weight in group $\mathrm{B}$ and $\mathrm{C}$ in comparison with $\mathrm{A}$ and $\mathrm{D}$ (Table 3).

Table 2: Symbiotic ELISA Mean of antibodies titer against $\mathrm{ND} \pm \mathrm{SE}$, with two different IBD vaccines

\begin{tabular}{lcccccc}
\hline \multirow{2}{*}{ Groups } & \multicolumn{5}{c}{ Mean of antibodies titer against IBD (age /days) } \\
\cline { 2 - 6 } & 1 & 7 & 14 & 21 & 28 & 35 \\
\hline Group A & $8008 \pm 779 \mathrm{a}$ & $4572 \pm 559 \mathrm{a}$ & $4269 \pm 543 \mathrm{a}$ & $2631 \pm 459 \mathrm{a}$ & $3024 \pm 319 \mathrm{a}$ & $1930 \pm 553 \mathrm{bc}$ \\
Group B & $8022 \pm 1068 \mathrm{a}$ & $6501 \pm 1970 \mathrm{a}$ & $3459 \pm 580 \mathrm{ab}$ & $1942 \pm 172 \mathrm{ab}$ & $4220 \pm 773 \mathrm{a}$ & $3941 \pm 571 \mathrm{~b}$ \\
Group C & $7960 \pm 782 \mathrm{a}$ & $4596 \pm 1161 \mathrm{a}$ & $2545 \pm 952 \mathrm{ab}$ & $1388 \pm 226 \mathrm{~b}$ & $3119 \pm 775 \mathrm{a}$ & $5940 \pm 1685 \mathrm{a}$ \\
Group D & $8062 \pm 1023 \mathrm{a}$ & $4549 \pm 1309 \mathrm{a}$ & $1716 \pm 435 \mathrm{~b}$ & $0.0 \pm 0 \mathrm{c}$ & $0.0 \pm 0 \mathrm{~b}$ & $0.0 \pm 0 \mathrm{c}$ \\
\hline
\end{tabular}

$\mathrm{a}, \mathrm{b}, \mathrm{c}$ The different superscript in each column means statistically different significantly at $\mathrm{P}<0.05$.

Table 3: Mean of body weight $(\mathrm{gm}) \pm \mathrm{SE}$ with two different IBD vaccine

\begin{tabular}{lcccccc}
\hline \multirow{2}{*}{ Groups } & \multicolumn{5}{c}{ Mean of antibodies titer against IBD (age /days) } \\
\cline { 2 - 6 } & 1 & 7 & 14 & 21 & 28 & 35 \\
\hline Group A & $41.8 \pm 1.1 \mathrm{a}$ & $201.9 \pm 3.61 \mathrm{a}$ & $471.8 \pm 11.1 \mathrm{~b}$ & $912.3 \pm 30.1 \mathrm{a}$ & $1549.8 \pm 73.4 \mathrm{~b}$ & $2263.2 \pm 153.3 \mathrm{ab}$ \\
Group B & $41.6 \pm 1.2 \mathrm{a}$ & $197.3 \pm 7.4 \mathrm{a}$ & $455.7 \pm 18.3 \mathrm{ab}$ & $986.8 \pm 21.8 \mathrm{a}$ & $1687.1 \pm 100 \mathrm{a}$ & $2369 \pm 172.4 \mathrm{a}$ \\
Group C & $42.1 \pm 1 \mathrm{a}$ & $203.3 \pm 4.8 \mathrm{a}$ & $511.7 \pm 15.6 \mathrm{a}$ & $982.1 \pm 23 \mathrm{a}$ & $1755.8 \pm 89.1 \mathrm{a}$ & $2380 \pm 280.2 \mathrm{a}$ \\
Group D & $39.8 \pm 1.2 \mathrm{a}$ & $202.6 \pm 2.6 \mathrm{a}$ & $505.4 \pm 11.3 \mathrm{a}$ & $977.7 \pm 23.1 \mathrm{a}$ & $1679.8 \pm 76 \mathrm{a}$ & $2295.2 \pm 187.5 \mathrm{a}$ \\
\hline
\end{tabular}

$\mathrm{a}, \mathrm{b}, \mathrm{c}$ The different superscript in each column means statistically different significantly at $\mathrm{P}<0.05$.

\section{Histological findings}

The histological examination of bursal sections in group $\mathrm{A}$ at 14 days' post vaccination showed degeneration and necrosis of follicular lymphocytes (lymphoid follicles) associated with folding and hyperplasia of the epithelial cells in basement membrane. Another section showed sever fibrosis and hemorrhage with infiltration of mononuclear inflammatory cells in the inter lobular and inter follicular space (Figure 1a), while the bursal sections at $28 \mathrm{dpv}$ showed more sever histological changes in comparison with $14 \mathrm{dpv}$ and discriminated by medullary vacuolation, depletion of B-lymphocytes, sever degeneration, inter follicular fibrosis and necrosis of follicular lymphocytes (lymphoid follicles) (Figure 1b).

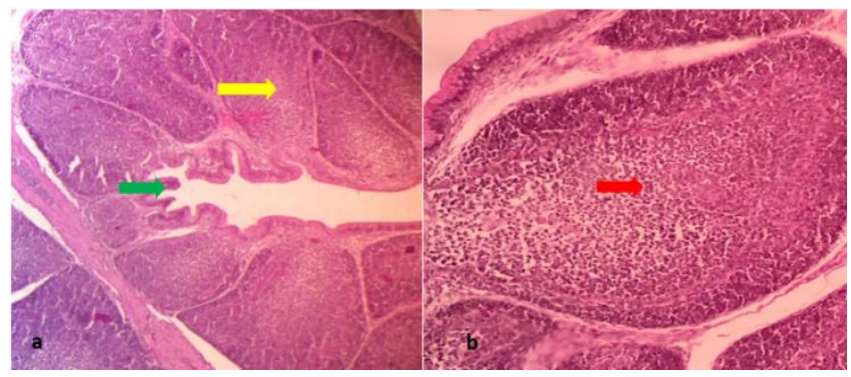

Figure 1: a- Bursal tissue14 day post vaccination explain degeneration and necrosis (arrow) of follicular lymphocytes with folding and hyperplasia (arrow) of the epithelial cells in basement membrane. H\&E. 40x. b- bursal sections at $28 \mathrm{dpv}$ showed sever histological changes and discriminated by medullary depletion of B-lymphocytes (arrow). H\&E. 100x.
The examined sections in group B at $14 \mathrm{dpv}$ revealed a distinct odema between the lymphoid follicles associated with lymphatic depletion (Figure 2a). Degeneration and necrosis of medullary lymphocytes, thickening and congestion of blood vessels in the inter follicular space and infiltration of mononuclear inflammatory were observed at $28 \mathrm{dpv}$ (Figure 2b).

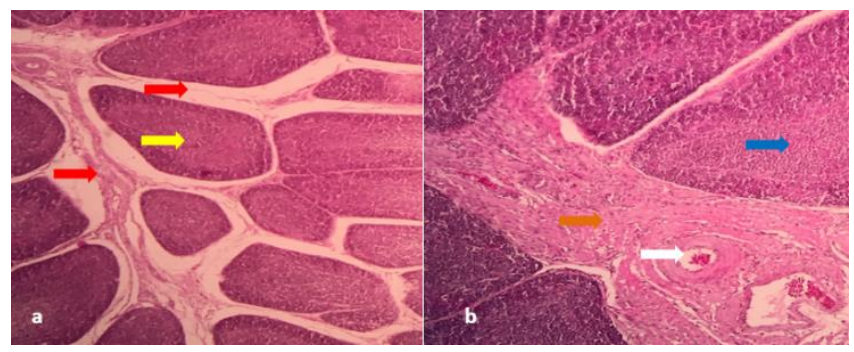

Figure 2: a-examined sections in group B at $14 \mathrm{dpv}$ with distinct oedema (arrow) between the lymphoid follicles associated with lymphatic depletion (arrow). H\&E. 40x. bdegeneration and necrosis (arrow) of medullary lymphocytes, thickening (arrow) and congestion (white arrow) of blood vessels in the inter follicular space at 28 dpv. H\&E. 40x.

The bursal sections of group $\mathrm{C}$ at $14 \mathrm{dpv}$ showed hemorrhage in the inter follicular space with loss of demarcation between cortex and medulla (Figure 3a), while at $28 \mathrm{dpv}$ the examined sections revealed mild depletion in lymphoid follicles, distention of inter follicular space and hyperplasia of epithelial cells (Figure 3b). 


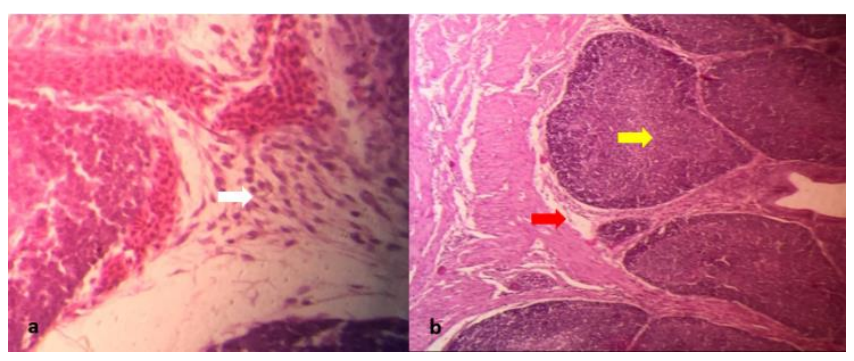

Figure 3: a- bursal sections of group $\mathrm{C}$ at $14 \mathrm{dpv}$ showed hemorrhage (white arrow) in the inter follicular space with loss of demarcation between cortex and medulla. H\&E. $100 x$. b- $28 \mathrm{dpv}$ of the examined sections revealed mild depletion (arrow) in lymphoid follicles, distention (arrow) of inter follicular space and hyperplasia of epithelial cells. H\&E. 40x.

Finally, the sections of group D showed the normal architecture of bursal tissue which characterized by presence of intact lymphoid follicles of variable size and separated by thin connective tissue which contain inter follicular blood vessels (Figure 4).

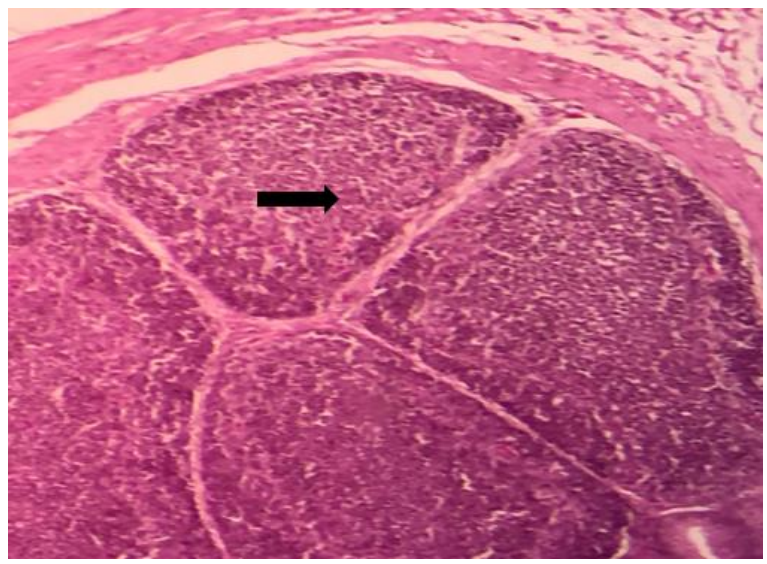

Figure 4: Normal architecture of bursal tissue which characterized by presence of intact lymphoid follicles of variable size and separated by thin connective tissue (arrow). H\&E. 100x.

\section{Discussion}

In the poultry industry, immunization against IBD is archived by administration of commercially live, inactivated or recombinant IBD vaccines (13).

Recurrent or regular vaccination of breeder hens produces a prevailing high serum antibodies and offspring chickens have maternal-derived antibodies (MDAbs) from breeder hens via the yolk sac that offer protection for many days after hatching (14).

The ELISA technique is commonly used as a standard serological tool for detection of antibody titers against IBD in poultry farms (15).
The titer of MDAbs is steady and considered as safe to moderate at the first few days of age and declined gradually as a result of the releasing of these Abs from yolk sac in the first 3 days of age and then these MAbs undergo catabolism; hence the titer decreased with age (16).

In group A it was observed that two doses of live vaccine at 7 and 21 gave protective Abs titers and this result agreed with Bughio et al. (17) who mentioned that two doses of vaccine one at 10-12 day of their age either with an intermediate or hot strain and other at 22-24 days of age induced protective antibodies against IBD.

In group B (Icx) vaccine resulted in an early release of viral antigen from captured $A b s$ in this vaccine that exhibited on immune response as the IBD ELISA titer and this result disagreed with Sedeik et al. (18) who mentioned that the Icx vaccine produced a weak immune response at 5 weeks of age which may be explained by the virus in the vaccine being still captured with some virus neutralizing Abs that leading to weak induction of immune response, while there is an agreement with another result of Sedeik et al. (18) when compared the results of vaccination of live and immune complex vaccine at 4 weeks of age and the titer of Abs gave 100\% protection against the challenge. The MDAbs titer showed gradual decrease weekly in group $\mathrm{C}$ and D (non-vaccinated groups) and became non protective as a result of catabolic degradation of these Abs within the body $(19,20)$.

Finally, Sedeik et al. (18) summarize that the Icx vaccine at one-day old was safer and provided higher protection which is similar to our results.

Thus the type of the vaccine is one of the key aspects that detects and regulates the efficacy of IBD vaccination (21).

This study also was designed to determine the interaction between the common commercial vaccines used to control the endemic diseases in Iraqi poultry farms. In table 2 as a result of comparison of Abs titer of group B and $\mathrm{C}$ with group A the significant difference appeared at 14,21 days of age and this result disagreed with finding of (22) which who observed that IBDV infection or vaccination decrease the immune response of guinea fowls to Newcastle disease vaccine "LaSota", in addition to disagreement with finding by (23) when they cited that vaccination of chicken with ND vaccine "LaSota" which adversely affected by IBD vaccine when administered primarily.

The significant difference between the groups appear at 35 days of age and the high titer of Abs was in group C compared with group A because significant decline of Abs production of chickens against ND vaccine when administered after IBD vaccine of infection $(24,25)$.

While the significant difference between group C and B may be due to the releasing of live intermediate plus strain form Icx vaccine captured Abs and the depletion of B-cell in the bursa of Fabricius was remarkably less severe than after vaccination with Icx vaccine (26). The catabolic 
character of Abs resulted to regular decline of MDAbs against ND in group D (negative control) with age.

The main significant differences in body weigh occurred at 28, 35 days between groups B, C and D compared with A and this results disagreed with Okwor et al. (27) when they mentioned that mixed vaccination against ND and IBD using live vaccines did not show alteration the immune response, feed intake and weight gain in healthy broilers.

The B-lymphocytes necrosis and depletion in group A is agreement with Khatri et al. (28) when this depletion was associated with loss of large number of B-lymphocytes post vaccination as a results of targeting of bursal tissue with virus vaccine (29).

In group B the lymphatic depletion, degeneration and necrosis of medullary B- lymphocytes occurred as a results of virus replication in bursa (30) and this lesion is due to the effect of induction of chemical mediators especially cytokines that released by macrophages (28).

While the mild depletion of B-lymphocytes and no alteration of the normal architecture of the bursa is in agreement with Igwe et al. (31).

\section{Conclusions}

The Icx vaccine improves the immune response after IBD and ND vaccination and expands body weight in comparison with live IBD vaccine.

\section{Acknowledgment}

Authors would like to thanks the College of Veterinary Medicine, University of Mosul, Mosul, Iraq.

\section{Conflict of interest}

The authors declare that there is no conflict of interest.

\section{References}

1. Muller H, Islam MR, Raue R. Research on infectious bursal disease: the past, the present and the future. Vet Microbiol. 2003;97:153-165. DOI: $10.1016 /$ j.vetmic. 2003.08 .005

2. Glisson JR, McDougald LR, Nolan LK, Suarez DL, Nair VL. Diseases of poultry. $13^{\text {th }}$ ed. Ames: Iowa State Press; 2013. 109-128 p.

3. Zaheer A, Inayat S, Naeem K, Malk SA. Comparative Immune response pattern of commercial: Infectious bursal disease vaccine against field isolates. Pak Inter J Poult Sci. 2003;2:449-453. DOI: 10.3923/ijps.2003.449.453

4. Maas RA, Venema S, Oei HL, Pol JMA, Claassen IJTM. Efficacy of inactivated infectious bursal disease (IBD) vaccines: Comparison of serology with protection of progeny chickens against IBD virus strains of varying virulence. Avian Pathol. 2001;30:345-54. DOI: $\underline{10.1080 / 03079450120066359}$

5. Kelemen M, Forgach K, Ivan J, Palya V, Suveges T. Pathological and immunological study of an in ovo complex vaccine against infectious bursal disease. Acta Vet Hung. 2000;48:443-54. DOI: $\underline{10.1556 / 004.48 .2000 .4 .7}$

6. Rautenschlein S, Kraemer C, Vanmarcke J, Montiel E. Protective efficacy of intermediate and intermediate plus infectious bursal disease virus (IBDV) vaccines against very virulent IBDV in commercial broilers. Avian Dis. 2005;49:231-7. DOI: 10.1637/7310$112204 \mathrm{R}$

7. Jacquinet C, Gardin Y. Monitoring the vaccine intake of a Gumboro vaccine of complex immune type applied to the hatchery. Interest and examples of follow-up in comparison with a traditional vaccination method. Proceedings of the Journées de Recherche Avicole, Tours, France; 2011.

8. Michell BC, Gomes AD, Baiao NC, Resende M, Lara LC, Martins NRS. Effect of maternally-derived antibodies on the performance and immunity of broilers induced by in ovo or post-hatching immunizations with a live vaccine against infectious bursal disease. Brazil J Poult Sci. 2009;1:57-63. DOI: 10.1590/S1516635X2009000100009

9. Block H, Meyer-Block K, Rebeski D E, Scharr H, de Wit S, Rohn K, Rautenschlein S. A field study on the significance of vaccination against infectious bursal disease (IBDV) at the optimal time point in broiler flocks with maternally derived IBDV antibodies. Avian Pathol. 2007;36:401-409. DOI: $10.1080 / 03079450701589175$

10. Bancroft JD, Marilyn G. Theory and practice of histological techniques. $6^{\text {th }}$ ed. New York: Churchill Livingstone; 2008.

11. Al-Bajaril SA, Al- Akash1 MA, Ismail HK. Experimental detection of antioxidant and atherogenic effects of grapes seeds extracts in rabbits. Iraqi J Vet Sci. 2019.33(2):243-249. DOI: 10.33899/ijvs.2019.162881

12. Steel RD, Torrie JH, Dickey DA. Principles and procedures of statistics: A biometrical approach. $3^{\text {rd }}$ ed. New York: McGraw-Hill Book Co; 1997.

13. Muller H, Mundt E, Eterradossi N, Islam MR. Current status of vaccines against infectious bursal disease. Avian Pathol. 2012;41:133139. DOI: $\underline{10.1080 / 03079457.2012 .661403}$

14. Wyeth PJ, Chettle N. Comparison of the efficacy of four inactivated infectious bursal disease oil emulsion vaccines. Vet Rec. 1982;110: 359-361. DOI: $10.1136 /$ vr.110.15.359

15. Dey S, Pathak DC, Ramamurthy N, Maity HK, Chellappa MM. Infectious bursal disease virus in chickens: prevalence, impact, and management strategies. Vet Med. 2019;10:85-97. DOI: 10.2147/VMRR.S185159

16. Cazaban C, Swart WBF, Rietema RMW, Wit JJD, Palya, V, Gardin Y. Field Assessment of an Immune-Complex Infectious Bursal Disease Vaccine in Chicks Born to Non-Hyperimmunized Broiler Breeders. J Vet Sc Anim Husbandry. 2018;6 (3):1-10. DOI: 10.15744/2348-9790.6.302

17. Bughio E, Jatoi AS, Memon M, Bughio R, Khoso PA, Khoso ZA, Baloch AA. Effect of age and route of administration on the efficacy of live infectious bursal disease vaccines in broiler. Sarhad J Agricul. 2017;33(2):232-239. DOI: 10.17582/journal.sja/2017/33.2.232.239

18. Sedeik ME, El-shall NA, Awad AM, Abd El-Hack ME, Alowaimer AN, Swelum AA. Comparative evaluation of HVT-IBD Vector, immune complex, and live IBD vaccines against vvIBDV in commercial broiler chickens with high maternally derived antibodies. Animals. 2019;9:72. DOI: 10.3390/ani9030072

19. Chansiripornchai N, Sasipreeyajan J. Comparison of the efficacy of the immune complex and conventionally live vaccine in broilers against infectious bursal disease infection. Thai $\mathrm{J}$ Vet Med. 2009;39:115-120. [available at]

20. Rojs OZ, Krapezi U, Slavec B, Jursic-Cizerl R. Field efficacy of different vaccines against infectious bursal disease in broiler flocks. Acta Vet Hung. 2011;59:385-398. DOI: 10.1556/AVet.2011.016

21. Hair MS, Salina H, Hafiza SJ. In ovo vaccination against infections bursal disease in broiler chickens. J Vet Malaysia. 2000;2:63-69. [available at]

22. El-Yuguda A D, Wachida N, Baba SS. Interference of infectious bursal diseases (IBD) virus and vaccine with the immune responses of guinea fowls to newcastle disease lasota vaccination. African J Biomed Res. 2007;10:189-192. DOI: 10.4314/ajbr.v10i2.50630

23. Ali AS, Abdalla MO, Mohammed MH. interaction between newcastle disease and infectious bursal disease vaccines commonly used in Sudan. Inter J Poult Sci. 2004;3 (4):300-304. DOI: $\underline{10.3923 / i j p s .2004 .300 .304}$ 
24. El-Yuguda AD. Effects of material antibodies and vaccine interactions on specific antibody response of Village chickens to single or combined Newcastle disease and infectious bursal disease vaccines [MVSc dissertation]. Maiduguri: University of Maiduguri, Nigeria; 2000.

25. Rabee RHS, Jaber IM. The interference of Newcastle, avian influenza and infectious bursal disease vaccines with the efficiency of IB vaccine in broiler chicks by using quantitative RT-PCR test. Iraqi $\mathbf{J}$ Vet Sci. 2019;33(1):105-109. DOI: 10.33899/ijvs.2019.125510.1032

26. Jeurissen SHM, Janse EM, Lehrbach PR, Haddad TEE, Avakia TA, Whiteillt TCE. The working mechanism of an immune complex vaccine that protects chickens against infectious bursal disease. Immunol. 1998;95:494-500. DOI: $10.1046 / \mathrm{j} .1365-2567.1998 .00617 . \mathrm{x}$

27. Okwor E C, Eze D C, Anyanwu M U, Okpe CB, Eze PC. Effects of mixed vaccinations against newcastle disease and infectious bursal disease on immune response, feed consumption and weight gain in broilers. J Agricul Vet Sci. 2013;6(3):63-68. [available at]

28. Khatri M, Sharma JM. Replication of infectious bursal disease virus in macrophages and altered tropism of progeny virus. Vet Immunol Immunopathol. 2007;117:106-115.

DOI: 10.1016/j.vetimm.2007.02.002

29. Gardner H, Kerry K, Riddle M, Brouwer S, Gleeson, L. Poultry virus infection in Antarctic penguins. Nature. 1997;387:245. DOI: $10.1038 / 387245 \mathrm{a} 0$

30. Rautenschlein S, von Samson G, Haase C. A comparison of immune responses to infection with virulent infectious bursal disease virus (IBDV) between specific-pathogen-free chickens infected at 12 and 28 days of age. Vet Immunol Immunopathol. 2007;115:251-260. DOI: 10.1016/j.vetimm.2006.11.002

31. Igwe A, Nnsewoa UE, Eze DC, Abbac Y, Okoyeb JOA. Increased doses of La Sota vaccine increased Newcastle disease antibody response significantly in broiler chickens (Gallus gallus domesticus). J Appl Anim Res. 2019;47(1):423-428. DOI: $\underline{10.1080 / 09712119.2019 .1645675}$

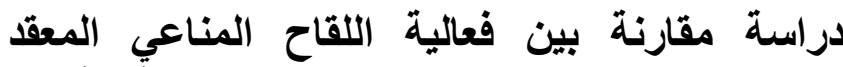

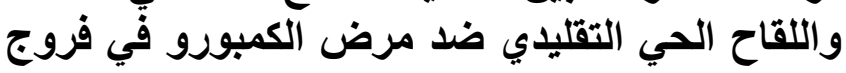 اللحم}

فنار ابلح اسحق' ، هناء خليل إسماعيلَ وعبدالواحد عبدالحكيم واحدّ"

'فرع الأحياء المجرية، 'فرع الأمراض وأمراض الدواجن، كلية

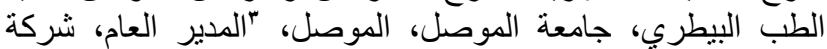
يار ابرز للاو اجن و الخدمات البيطرية، أربيل، العر اقل

الخلاصة

هدفت هذه الدراسة إلى تقييم الاستجابة المناعية و التغيرات النسجية

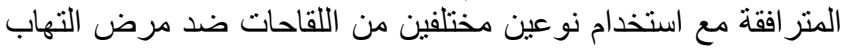

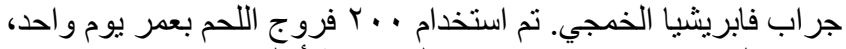

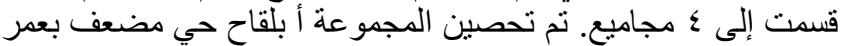

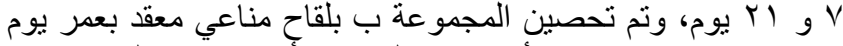

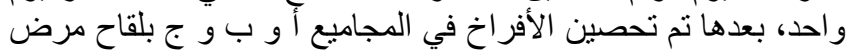

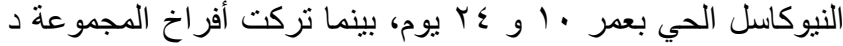

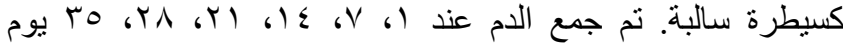

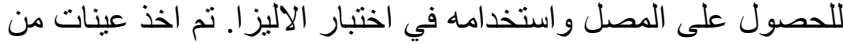

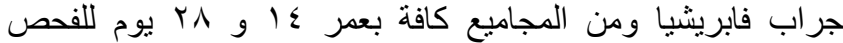
النسجي. أظهرت نتائج التحصين في المجموعة أ أرتفاعا في معيار

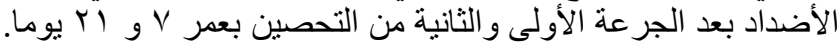

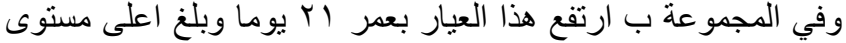

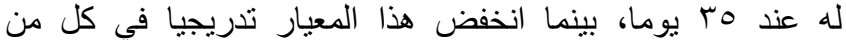

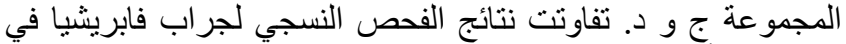

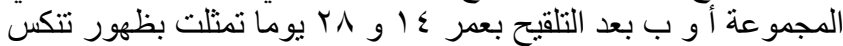

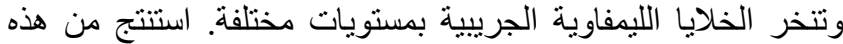
الدراسة بأن التحصين بلقاح مناعي معقد يحسن من الاستجابة المناعية

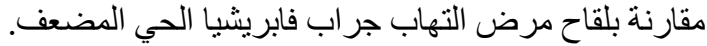

